(b) Consideration of the U.S.S.R. proposal to hold the XVth General Assembly in Warsaw, Poland, in 1973.

20. The election of a President, three Vice-Presidents, a General Secretary, and an Assistant General Secretary.

21. Addresses by the retiring and newly-elected Presidents.

22. Closing ceremonies.

At the first session of the General Assembly, to be held on TUESDAY 18 AUGUST, 1970, items 1-11 of the above agenda will be considered. The remaining items, and any which may have been adjourned from the first session, will be considered at the second session, to be held on THURSDAY 27 AUGUST, 1970.

\title{
FIRST SESSION
}

Held in The Dome at Brighton, Sussex, England, on Tuesday, 18 August 1970 at $15^{\mathrm{h}} 00^{\mathrm{m}}$

Professor Dr Otto Heckmann, President, in the chair

1. Formal Opening. The President spoke a few words of welcome to the Members of the Union, invited participants and their guests, representatives of Adhering Countries, representatives of sister Unions and other organizations, and formally declared open the first session of the fourteenth General Assembly of the Union.

He welcomed in particular the official representatives of ICSU and other scientific Unions as follows:

ICSU: Professor V. A. Ambartsumian

IUGG (International Union of Geodesy and Geophysics): Professor P. Tardi

IUGS (International Union of Geological Sciences): Dr G. Fiedler, Dr P. M. Millman

URSI (Union Radio Scientifique Internationale): Professor W. N. Christiansen

COSPAR (Committee on Space Research): Professor C. de Jager, Dr. Z. Švestka

IAB (ICSU Abstracting Board): Dr J. B. Sykes

CST (Committee on Science Teaching): Professor Edith A. Müller

IUCSTP (Inter-Union Commission on Solar-Terrestrial Physics): Dr H. Friedman, Dr Z. Švestka

IUTAM (International Union of Theoretical and Applied Mechanics): Dr M. J. Lighthill

Joint Commission on Spectroscopy: Dr G. Herzberg, Professor B. Edlén

BIMP (Bureau International des Poids \& Mesures): Dr J. Terrien

IUAA (International Union of Amateur Astronomers): Messrs L. Baldinelli, F. M. Flinch, H. Miles, O. Oburka

The official representative of UNESCO could not attend for other serious engagements.

The President then suggested that a message of thanks be sent to H.R.H. The Duke of Edinburgh. This proposal was approved by acclamation.

The President continued by asking Members to stand while the General Secretary would read the names of Members who had died since the last meeting, or whose death had not been known at the time of that meeting. The General Secretary then read the following list:

Mrs Z. N. Aksent'eva, H. D. Babcock, A. Birkenmayer, Miss M. Bretz, S. Chapman, L. Cichowicz, L. d'Azambuja, G. Demetrescu, A. J. Deutsch, E. J. Dijksterhuis, J. Dufay, L. Egyed, G. Fayet, J. H. Focas, D. A. Frank-Kamenetskij, C. W. Gartlein, E. Gullón, S. E. Hajkin, K. Heinemann, L. G. Henyey, E. Hertzsprung, C. Hoffmeister, J. Ikaunieks, C. C. Kiess, H. Knox-Shaw, A. Kohlschütter, J. J. Kubikowski, N. I. Kucherov, A. I. Lebedinskij, Mrs S. L. McDonald, S. G. Makover, A. V. Markov, O. F. Mathias, R. W. Michie, A. V. Nielsen, Miss R. J. Northcott, Mrs S. V. Romanskaya, L. I. Semenov, E. C. e Silva, E. Vassy, S. C. Venter, M. H. Wrubel. 
2. Appointment of official interpreters. The following four official interpreters were appointed by acclamation:

from English to French: L. Houziaux, S. A. J. Malaise

from French to English: P. R. Demarque, H. Reeves

1. (cont.) The President took the floor and addressed the Assembly as follows:

'During the past three years the members of the Executive Committee, the Officers of the IAU and - I am sure - many members of the Union have felt with deep concern what our predecessors felt and what the responsible men in the Union will feel in the forseeable future: Namely that the growth and the health of the Union could come into conflict with each other. Changes of one sort or other will be inevitable.

But the present Executive Committee is of the opinion that the development of the Union has been sound until now. The Executive Committee has authorized the President to convey to you, in very short words, a few directives, which are only meant as an advice, but which are supported by careful consideration of many factors and as a resonance of many single voices:

1. It has been proposed that it would be a good thing to split the Union into a small number of larger sections. Well, you do not find in the Statutes, neither in the old nor in the new version, a paragraph stating that it is an aim of the IAU to preserve the unity of astronomy. But we believe that this is the vital and basic principle according to which the Union has lived so far and will have to live for quite a number of years to come. It is true that new methods, techniques, theories and discoveries change the scope of astronomy very rapidly. However, everybody knows quite well what astronomy is and how the new developments fit into it. A radioastronomer may get deeply involved in fundamental astronomy and astrometry; a high frequency astrophysicist may derive deep satisfaction from his contact with celestial mechanics; and so on. There still exists the common language, even though we have to confess that some newcomers will have to learn it. We believe very strongly that splitting the Union would very soon result in disrupting the unity of astronomy as such. We believe that such a splitting is unnecessary because the structure of the Union is very elastic and with the new version of the Statutes will become even more elastic.

It might be found necessary in the future to create new Commissions, or to merge and discontinue others when their tasks so require, more frequently than it has been done before. This will allow rapid adaptations.

2. It has been argued that Individual Membership has unnecessarily added to the growth of the Union. The present Executive Committee believes that Individual Membership is one of the Union's principal assets. Since the Membership of the Union is awarded only for active participation in astronomical research, it is rightly regarded as an international recognition of the individual's qualification. It is coveted by young astronomers all the world over and by scientists from neighbouring fields. This Individual Membership in one and the same organisation maintains very strongly the sense of unity of our science. Very few international organisations have introduced it and one may well ask whether those, which have not, have a life similar in intensity to that of the IAU.

3. Our General Assemblies are, to a certain extent, a consequence of Individual Membership. The Membership would have little sense if Members could not meet at one place and at one time at such intervals as to still remember the previous meeting. We know very well that the difficulties of organizing Assemblies like ours are very great. Yet we know also that other branches of science successfully organize congresses with at least twice the attendance of the largest IAU Assemblies. We see a promising line of development: A cluster of smaller meetings, symposia and colloquia, are organized immediately before and after our General Assemblies. It may be necessary, that the Union should pay more attention to the participation of astronomers from such countries which find it difficult to provide visa for more than one foreign country. Therefore the following development seems to be recommendable:

The General Assemblies should be made shorter, cutting off one or two days of their duration, concentrating more on topics which interest a wide attendance, such as Joint Discussions, Invited Discourses, and Joint Meetings of several commissions. On the other hand, Commission Meetings 
ought to be limited to a bearable number in order to increase the intensity of personal contacts. Commissions desiring to have 10 meetings or more should organize Colloquia of 2-3 days' duration in the same country.

4. A last point should not be forgotten: All the success of the Union depends on work, and very frequently on heavy work, which requires first class experts, and yet brings never any material compensation. The time spent by an individual on IAU matters is limited and is in addition to his main occupation.

The recollection 'how it is done' is an extremely important factor. We believe therefore very strongly that all transformations of the Union must be made continuously.

These are the ideas which I had to convey to you. They are not new but they are not always at hand at moments where they - according to our opinion - should be of some benefit.'

\section{French translation:}

\section{Allocution du Président}

Au cours des trois années qui viennent de s'écouler, les membres du Comité Exécutif, le bureau de l'UAI et, j'en suis convaincu, bien des membres de l'Union ont éprouvé profondément le même souci que nos prédécesseurs ont éprouvé, le même qu'éprouveront dans un avenir prévisible ceux qui auront la responsabilité des affaires de l'Union: je veux dire le sentiment que la croissance et la santé de l'Union pourraient bien entrer en conflit l'une avec l'autre. Des changements d'une sorte ou d'une autre seront inévitables.

Mais le Comité Exécutif actuel pense que, jusqu'à présent, le développement de l'Union est resté raisonnable. Le Comité Exécutif a donné au Président l'autorisation de vous exprimer, en peu de mots, quelques idées directrices qui n'ont d'autre prétention que d'être un avis, mais qui sont appuyées sur une étude soigneuse de nombreux facteurs, et sont aussi comme l'écho de nombreuses opinions individuelles.

1. On a proposé comme une bonne chose de diviser notre Union en un petit nombre de grandes sections. En fait, vous ne trouverez dans les Statuts (que ce soit sous l'ancienne ou sous la nouvelle version) aucun paragraphe donnant à l'UAI comme l'un de ses objets de préserver l'unité de l'astronomie. Mais nous pensons que ceci est pourtant le principe vital, et fondamental, selon lequel l'Union a vécu jusqu'à présent, et selon lequel elle devra vivre encore pendant pas mal đ'années. Il est vrai que la nouveauté dans les méthodes, les techniques, les théories, et les découvertes, modifie très rapidement les perspectives de l'astronomie. Pourtant, chacun sait bien ce qu'est l'astronomie, et comment s'y insèrent les développements récents. Un radioastronome peut devenir profondément impliqué dans des recherches d'astronomie fondamentale et d'astrométrie; un astrophysicien des hautes fréquences peut tirer de profondes satisfactions de ses contatcts avec la mécanique céleste... les exemples sont nombreux. Il existe aussi un langage commun - encore devons-nous admettre que quelques nouveaux venus doivent l'apprendre. Nous croyons très fermement que le découpage de l'Union aboutirait très vite à la destruction de l'unité de l'astronomie en tant que telle. Nous croyons qu'un tel découpage est inutile, car la structure de l'Union est d'une grande souplesse, et que, grâce aux nouveaux Statuts, elle deviendra plus souple encore.

On pourrait considérer comme necessaire dans l'avenir de créer de nouvelles commissions, d'en fusionner d'autres, voire d'en supprimer, quand l'évolution de leurs tâches l'exige ainsi - et ce, plus fréquemment que cela n'a été fait auparavant. Cette technique permettra des adaptations rapides...

2. On a dit que l'existence de membres de l'Union à titre individuel a contribué inutilement à la croissance de l'Union. Le Comité Exécutif actuel pense que l'appartenance individuelle à l'Union est l'un des atouts essentiels de l'Union. Puisque l'on n'accorde cette appartenance qu'à ceux qui participent activement à la recherche astronomique, elle est justement considérée comme la reconnaissance internationale des qualifications de l'individu concerné. Elle est briguée par les jeunes astronomes du monde entier comme par des chercheurs travaillant dans des disciplines voisines. L'appartenance individuelle à une unique organisation maintient fortement le sentiment de l'unité de notre science. Un très petit nombre d'organisations internationales ont introduit cette disposition 
dans leurs statuts, et l'on peut se demander si les organisations qui ne l'ont pas fait ont une vie aussi intense que celle de l'UAI.

3. Nos Assemblées Générales, dans une certaine mesure, sont une conséquence de l'appartenance individuelle. Celle-ci n'aurait aucun sens si les Membres ne pouvaient se réunir en un seul endroit, au même moment, à des intervalles assez courts pour qu'ils n'aient pas le temps d'oublier leur réunion précédente. Nous savons fort bien les énormes difficultés que rencontre l'organisation d'assemblées comme les nôtres. Nous savons aussi que d'autres disciplines scientifiques organisent des congrès auxquels participent deux fois plus de personnes qu'aux assemblées les plus importantes de l'UAI. Une direction très prometteuse de développement est maintenant en vue: une collection de réunions moins vastes, symposiums et colloques, s'organise immédiatement avant ou après nos Assemblées Générales. Il peut être nécessaire pour l'Union de considérer avec une attention toute spéciale la participation d'astronomes originaires de pays où il est difficile d'obtenir des visa plus d'un pays étranger; par suite, le processus que je vais maintenant décrire semble à recommander.

Les Assemblées Générales devraient être plus courtes, leur durée étant réduite d'un ou deux jours, et concentrer leurs activités sur des questions susceptibles d'intéresser le plus grand nombre, grâce aux discussions communes, aux conférences solennelles, aux réunions communes à plusieurs commissions. D'autre part, les réunions de commissions devraient être limitées à un nombre supportable, afin de permettre l'accroissement en intensité des contacts personnels. Les commissions qui souhaiteraient organiser une dizaine de réunions, ou même plus, devraient plutôt mettre sur pied des colloques de deux ou trois jours dans le même pays.

4. Un dernier point ne devrait pas être oublié: toute l'efficacité de l'Union dépend du travail de quelques-uns: c'est très souvent un travail très lourd, qui exige des experts de premier plan, et qui n'entraîne pour eux aucune compensation matérielle. Le temps passé par un individu au service de l'Union est limité, et il s'ajoute à son occupation principale. Il est extrêmement important de se rappeler comment se font les choses, et nous croyons par conséquent très fermement que les transformations de l'Union doivent se faire dans la continuité.

Telles sont les idées dont je voulais vous faire part. Elles ne sont pas neuves - mais elles ne sont pas toujours en mémoire aux moments précis où, à notre avis, elles pourraient être de quelque utilité...

3. Report of the Executive Committee. The General Secretary invited the Assembly to discuss the Report of the Executive Committee (see pp. 1-28), as printed and distributed before the General Assembly, and said that he was prepared to answer any questions that might be asked. There were no questions, and the Report was approved.

4. Report by the General Secretary. The General Secretary then read the following addendum to the Report of the Executive Committee, covering the period January-August 1970:

'My complementary report covers the activity of the Union during the period from 1 January to 31 July 1970.

The Executive Committee decided by correspondence on the following items:

(a) It approved the list of candidates for the officers of the IAU during the ensuing period of three years.

(b) It prepared the Activities Report, as printed and distributed before the General Assembly (see pp. 4-10), and a preliminary comprehensive budget of the IAU for 1971-73.

(c) It authorized the General Secretary to approach the Secretary General of ICSU with the request to have the year 1973 proclaimed the Year of Copernicus.

(d) It decided to propose to ICSU the creation of an Inter-Union Commission on the Moon, and it authorized the General Secretary to take this problem up with the International Unions concerned, and with COSPAR.

The Executive Committee proposes to the General Assembly the creation of two new Commissions: 
*Commission No. 47, Cosmology, presided over by Professor W. B. Bonnor in the first session.

* Commission No. 48, High Energy Astrophysics, to be presided over by Professor H. Friedman.

The Executive Committee also proposes to merge Commission No. 23 Carte du Ciel and Commission No. 24 'Stellar Parallaxes and Proper Motions' into one Commission No. 24 on Photographic Astrometry.

I trust these proposals will find your approval. (Proposals approved by show of hands.)

The Executive Committee examined in detail the applications of Cuba and Uruguay for adherence to the Union, and was happy to admit these two new Member Countries to the IAU.

The 50th anniversary of the foundation of the Union fell into the period which is just coming to its end. There were several occasions to look back at the past of the IAU and to compare it with other international organizations, similar in character. I could not help noticing that our predecessors, during all those past fifty years, always knew what they wanted. They shaped the IAU into an organization with a clear aim at international cooperation, an organization based on personal friedship and on willing assistance of its individual Members.

The reverse of the coin is finances. We had to restrict somewhat the bilinguality, we had to ask the Presidents of Commissions to shorten their reports on astronomy, we could only symbolically finance our scientific meetings. I wish sincerely to thank you for your understanding support which helped the Executive Committee to bring the finances of the Union back to normal, or almost so. And the Executive Committee is considering ways and means how to remove all restrictions on the length of Commission Reports.

However, the economies we had to achieve did in no way interfere with the scientific activity of the Union. We are looking back upon 9 Symposia and 12 Colloquia held by the IAU until the end of 1969. Six more Symposia are being held in conjunction with the General Assembly. The Summer Schools for Young Astronomers, organized with the financial aid of UNESCO in 1967, 1968 and 1969 were an outspoken success. We maintained over the period under review our traditional projects, and we are especially proud of the way Professor Minnaert knew to handle that of the Exchange of Astronomers. Thanks to an additional grant from ICSU it was possible to increase by $\$ 4000$ the sum at the disposal of Commission 38 and to award 50 grants to young astronomers for attending this General Assembly.

The Reports on Astronomy, prepared by the Presidents of Commissions, are a magnificent piece of work. I wish to thank all those who contributed to this success. I wish to thank UNESCO and ICSU for their financial help, I wish to thank the organizers of our Symposia and Colloquia, I wish to thank the organizers of the Summer Schools and I wish to thank the Presidents of Commissions for their selfless work and devotion to the Union.

My thanks are also due to our publishers. Eleven volumes were published - or will appear soon. The printing time, that is the time between the receipt of the manuscript by the printer and the appearance of the book, was 7 months on the average with a maximum of 10 and minimum of 5 months. The time needed by the Scientific Editors was on the average four and a half months and varied between 2 and 7 months. Our publications were well and widely advertised and their sales increased. They are not cheap. I did not find a solution to this problem.

You have in your hands the proposal by the Executive Committee for new Statutes of the Union. All changes and the reasons for them were mentioned in Information Bulletin Nos. 23 and 24 and I do not propose to repeat them here. You will find that the new proposal affects very little the current life of the Union. It makes the administration and organization of the growing Union easier, more flexible and more democratic. Permit me to stress one aspect:

There is no unique solution to the Statutes. Even if the substance is agreed upon, there remains an infinite number of possibilities in wording, sequence, degree of freedom and intentional vagueness. The question put before the General Assembly will not be to find all existing solutions to a mathematical game but to decide - with a certain amount of generosity - whether that particular solution is acceptable or not.

After this General Assembly the Union will have 2600 individual Members, 46 Adhering Countries, and 39 Commissions.' 
5. Report of the President of the proposals for membership of the Executive Committee.

The President reminded the Assembly that the rules adopted at the Moscow General Assembly provide for a Special Nominating Committee, appointed within one year following each General Assembly, to advise the Executive Committee on nominations for the new Executive Committee. The Special Nominating Committee elected at the XIIIth General Assembly in Prague, consisted of the present President, the former President Professor P. Swings, a Vice-President of the present Executive Committee, Professor W. N. Christiansen, and four Union Members:

Prof. M. Golay, Professor L. Goldberg, Professor Dr E. R. Mustel, and Dr D. H. Sadler.

The Special Nominating Committee made proposals to the Executive Committee which approved them unanimously as follows:

as President for the period 1970-73:

as Vice-Presidents for the period 1971-76:

as General Secretary:

as Assistant General Secretary:
Professor B. Strömgren, Denmark

Professor B. J. Bok, United States of America

Professor Sir Bernard Lovell, United Kingdom

Professor Dr E. R. Mustel, Union of Soviet Socialist Republics

Professor C. de Jager, The Netherlands

Professor Dr G. Contopoulos, Greece

The full Executive Committee would thus consist of the above six together with:

continuing Vice-Presidents: $\quad$ Dr M. K. V. Bappu, India

Professor L. Gratton, Italy

Dr J. Sahade, Argentina

in an advisory capacity:

Professor Dr O. Heckmann, former President, German Federal Republic

Dr L. Perek, former General Secretary, Czechoslovakia

In accord with the By-laws the formal election would take place at the final session of the General Assembly.

6. Announcements. At the request of the President, the General Secretary read

(a) the names of representatives of Adhering Countries, empovered to vote on their behalf;

(b) the names of representatives of Adhering Countries on the Nominating Committee.

\section{Country}

Argentina

Australia

Austria

Belgium

Brazil

Bulgaria

Canada

Chile

Colombia

Cuba

Czechoslovakia

Denmark

Finland

France

German Democratic Republic

German Federal Republic (a) Official Representative

J. Sahade

H. W. Wood

K. Ferrari d'Occhieppo

H. L. Vanderlinden

P. Kaufmann

N. Bonev

J. L. Locke

C. Anguita

J. Arias de Greiff

L. Larragoiti

V. Guth

M. Rudkjøbing

L. Oterma

A. Lallemand

H. Lambrecht

L. Biermann (b) Representative on

Nominating Committee

J. Sérsic

W. N. Christiansen

K. Ferrari d'Occhieppo

H. L. Vanderlinden

P. Kaufmann

N. Bonev

K. O. Wright

J. Stock

J. Arias de Greiff

L. Larragoiti

L. Kresák

K. Gyldenkerne

L. Oterma

J. Delhaye

G. Ruben

P. Wellmann 


\begin{tabular}{|c|c|c|}
\hline Greece & J. Xanthakis & D. Kotsakis \\
\hline Hungary & L. Detre & L. Detre \\
\hline India & G. Swarup & S. D. Sinvhal \\
\hline Iran & A. Therian & A. Therian \\
\hline Ireland & P. A. Wayman & T. E. Nevin \\
\hline Israel & Y. Ne'eman & Y. Ne'eman \\
\hline Italy & G. Righini & G. Righini \\
\hline Japan & S. Miyamoto & M. Huruhata \\
\hline Korea (P.D.R.) & not represented & not represented \\
\hline Mexico & P. Pishmish & A. Poveda \\
\hline Netherlands & J. H. Oort & A. Blaauw \\
\hline New Zealand & W. Davidson & W. Davidson \\
\hline Norway & E. Jensen & Ö Elgaröy \\
\hline Poland & W. Iwanowska & W. Zonn \\
\hline Portugal & M. G. Pereira de Barros & M. G. Pereira de Barros \\
\hline Roumania & C. Dramba & C. Dramba \\
\hline South Africa & F. J. Hewitt & F. J. Hewitt \\
\hline Spain & R. Carrasco & M. L. Arroyo \\
\hline Sweden & E. Holmberg & G. Larsson-Leander \\
\hline Switzerland & M. Golay & P. Bouvier \\
\hline Taiwan & M. Tsao & M. Tsao \\
\hline Turkey & N. Gökdogan & M. Hotinli \\
\hline U.A.R. & M. K. Aly & M. K. Aly \\
\hline United Kingdom & B. Lovell & P. O. Redman \\
\hline U.S.A. & J. L. Greenstein & B. J. Bok \\
\hline U.S.S.R. & V. A. Ambartsumian & A. G. Massevich \\
\hline Uruguay & G. Vergara & G. Vergara \\
\hline Vatican City State & P. J. Treanor & P. J. Treanor \\
\hline Venezuela & S. Sofía & S. Sofia \\
\hline Yugoslavia & P. Djurković & P. Djurković \\
\hline
\end{tabular}

Note: In some cases National Committees designated substitute delegates. In order to simplify the above list the names of the substitute delegates have been omitted.

(c) Acting Presidents. The General Secretary announced that the Executive Committee had invited:

W. Dieckvoss to act for A. A. Nemiro as President of Commission No. 8

R. G. Athay to act for M. N. Gnevyshev as President of Commission No. 12

G. M. R. Winkler to act for F. Zagar as President of Commission No. 31

A. Reiz to act for M. G. J. Minnaert as President of Commission No. 38

W. B. Bonnor to act for Ya. B. Zeldovich as President of Commission No. 47

The Acting Presidents were appointed for the duration of the General Assembly.

7. Finance Committee. In accord with the Statutes, the following Finance Committee, consisting of one representative of each Adhering Country, was appointed by the General Assembly:

$\begin{array}{llll}\text { Argentina } & \text { A. Feinstein } & \text { Japan } & \text { S. Miyamoto } \\ \text { Australia } & \text { J. P. Wild } & \text { Korea (P.D.R.) } & \text { not represented } \\ \text { Austria } & \text { K. Ferrari d'Ochieppo } & \text { Mexico } & \text { M. Mendez } \\ \text { Belgium } & \text { A. G. Velghe } & \text { Netherlands } & \text { C. A. Muller } \\ \text { Brazil } & \text { P. Kaufmann } & \text { New Zealand } & \text { W. Davidson } \\ \text { Bulgaria } & \text { M. Popova } & \text { Norway } & \text { Ö. Elgaröy } \\ \text { Canada } & \text { V. Gaizauskas } & \text { Poland } & \text { S. Piotrowski } \\ \text { Chile } & \text { C. Anguita } & \text { Portugal } & \text { M. G. Pereira de Barros }\end{array}$




$\begin{array}{llll}\text { Colombia } & \text { J. Arias de Greiff } & \text { Roumania } & \text { C. Dramba } \\ \text { Czechoslovakia } & \text { B. Onderlička } & \text { South Africa } & \text { F. J. Hewitt } \\ \text { Denmark } & \text { A. Reiz } & \text { Spain } & \text { J. O. Cardùs } \\ \text { Finland } & \text { L. Oterma } & \text { Sweden } & \text { A. Elvius } \\ \text { France } & \text { H. Andrillat } & \text { Switzerland } & \text { U. Steinlin } \\ \text { G.D.R. } & \text { K. H. Schmidt } & \text { Taiwan } & \text { H. Tsao } \\ \text { G.F.R. } & \text { W. Fricke } & \text { Turkey } & \text { A. Kiral } \\ \text { Greece } & \text { L. N. Mavridis } & \text { U.A.R. } & \text { A. S. Asaad } \\ \text { Hungary } & \text { L. Dezsö } & \text { U.K. } & \text { D. W. N. Stibbs } \\ \text { India } & \text { R. V. Karandikar } & \text { U.S.A. } & \text { K. A. Strand } \\ \text { Iran } & \text { A. Therian } & \text { U.S.S.R. } & \text { E. K. Kharadze } \\ \text { Ireland } & \text { P. A. Wayman } & \text { Vatican } & \text { F. C. Bertiau } \\ \text { Israel } & \text { Y. Ne'eman } & \text { Venezuela } & \text { S. Sofía } \\ \text { Italy } & \text { M. Cimino } & \text { Yugoslavia } & \text { P. Djurković }\end{array}$

Note: In some cases National Committees designated substitutes. For the sake of simplicity the names of the substitute delegates have been omitted in the above list.

8. Resolutions Committee. At the request of the President, the General Secretary explained that the duties of the Resolutions Committee were to advise the Executive Committee in respect of proposals for resolutions submitted by Commissions, with a view to recommending to the General Assembly which proposals should formally be submitted for consideration by the General Assembly. The General Assembly appointed J. H. Oort and D. H. Sadler to serve on the Resolutions Committee. The General Secretary and the Assistant General Secretary were to attend the meeting of the Resolutions Committee in an advisory capacity.

9. Statutes and By-laws. The General Secretary said that the text of the revised Statutes and By-laws had been prepared by a special Statutes Committee and approved by the Executive Committee. The corrections suggested by the French National Committee have been taken into consideration in the French version published in Information Bulletin No. 24. With this in mind, the General Secretary moved that the new Statutes and By-laws be adopted and that they become valid from 1 September 1970 on. This motion would be put to the vote at the final session.

10 and 11. Consideration of proposals for resolutions. The proposals for resolutions submitted by Adhering Organizations or National Committees were read by the General Secretary as follows:

(a) (Australia) to reconsider the decision to allocate the relative length of the Reports on Astronomy of the various Commissions on the apparently arbitrary basis of the length in the 1967 report.

(b) (Belgium) to recommend the introduction of a fundamental course in Astronomy and Geodesy in the curricula of Technical Universities.

(c) (Poland) to hold under the auspices of the IUHPS and IAU a Symposium commemorative of the 500th anniversary of the birth of Copernicus in Torun, Poland, and a Symposium on Cosmology in Warsaw, Poland, in 1973.

(d) (U.A.R.) to create a special Commission for Exchange of Equipment within the IAU.

(e) (U.S.S.R.):

(i) To proclaim the year 1973 the year of Copernicus and to bring this proposal before the UNESCO.

(ii) To hold the XVth General Assembly of the IAU in Warsaw, Poland, in commemoration of the 500th anniversary of the birth of this great scientist (see also point 19).

(iii) To investigate the possibility of less expensive IAU publications and thus to create conditions for a reduction of the unit of contribution paid by Adhering Countries.

(iv) To extend the interval between two General Assemblies of the IAU from 3 to 4 years as from 1973 onwards, and to pay more attention to scientific meetings with smaller attendance. 
(v) To create within one of the IAU Commissions a Sub-commission on the Physics of Unstable Stars.

The General Secretary then read the proposals for resolutions submitted by Commissions as follows:

(a) (Commission No. 6) recommends that the IAU subvention to the IAU Telegram Bureau be maintained at its present value of $\$ 1600$ per triennium.

(b) (Commission No. 16) proposes that $\$ 1500$ be allocated to the Centre de documentation sur les planètes à Meudon for 1971-73.

(c) (Commission No. 17) propose que l'Assemblée Générale accepte les 500 noms proposés par la Commission $\mathrm{N}^{\circ} .17$ pour désigner les cratères de la face arrière de la Lune et qu'elle attribue à la Commission $\mathrm{N}^{\circ} .17$ pour les années $1971-73$ une subvention de $\$ 2000$ pour aider le fonctionnement des groupes de travail spécialisés de cette Commission.

(d) (Commission No. 23) proposes that a resolution be discussed by the General Assembly concerning the future of the Helsingfors Observatory which is threatened to be closed down by the authorities.

(e) (Commissions No. 23 and 24) propose the merger of Commission No. 23 'Carte du Ciel' and Commission No. 24 on Stellar Parallaxes and Proper Motions.

(f) (Commission No. 33) proposes that the General Assembly resolve to omit the superscript II from the new galactic coordinates that should be simply $1, b$; the old coordinates should retain the superscript I.

(g) (Commission No. 27) proposes to allocate to Commission No. 27 an annual subvention of $\$ 1000$ for the continued publication of the General Catalogue of Variable Stars.

(h) (Commission No. 46) recommends the introduction of a fundamental course in astronomy in University curricula.

The General Secretary explained that these proposals would first be considered by the relevant Commissions and then passed on to the Resolutions Committee for further recommendation. A number of other proposals received from Commissions in draft form would first be discussed by the Commissions.

The General Secretary reminded that the formal vote on resolutions would take place at the final session of the General Assembly, according to By-laws.

The General Secretary then announced that all other items of agenda would be deferred until the next session of the General Assembly, pending reports from various Commissions and Committees.

The President thanked the interpreters and formally adjourned the meeting at $16^{\mathrm{h}} 15^{\mathrm{m}}$.

\section{FINAL SESSION}

Held in The Dome at Brighton, Sussex, England, on Thursday 27 August 1970 at $10^{\mathrm{h}} 00^{\mathrm{m}}$

Professor Dr O. Heckmann, President, in the chair

The Chairman referred to the General Secretary's motion made at the first session and put to the vote of the General Assembly the new Statutes and By-laws of the International Astronomical Union, as proposed by the Executive Committee. The Statutes and By-laws were adopted by show of hands of the official representatives of Adhering Organizations.

12 and 13. Report of the Finance Committee and consideration of the unit of subscription.

At the first session of the General Assembly a Finance Committee had been appointed to examine the accounts of the Union for the preceding three years and to consider the budget of the IAU for the coming three years, as prepared by the Executive Committee. The Chairman now called upon 